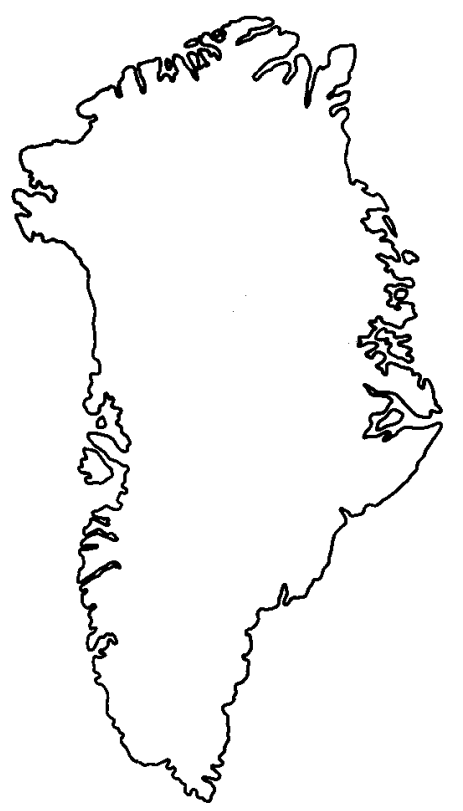

\title{
New Cambrian faunas from Peary Land, eastern North Greenland
}

\author{
A.R. Palmer and John S. Peel \\ Early, Middle and Late Cambrian faunas from Peary Land, \\ eastern North Greenland, are briefly documented. The Early \\ Cambrian faunas of the lower Brønlund Fjord Group are assig- \\ ned to the Bonnia-Olenellus Zone, although olenellids from the \\ underlying Buen Formation may be older. Strata from the upper \\ Brønlund Fjord Group with Middle Cambrian faunas are see- \\ mingly separated from the Lower Cambrian by a discontinuity, \\ without representation of early Middle Cambrian zones. Faunas \\ from lower beds of the overlying Tavsens Iskappe Group span \\ the Middle-Late Cambrian boundary. Upper beds of the Tavsens \\ Iskappe Group are assigned to the Late Cambrian, but corrobo- \\ rative faunal evidence is not yet available.
}

A.R.P. Department of Earth \& Space Science, State University at Stony Brook, Stony Brook, N.Y. 11794, U.S.A.

J.S.P. Grønlands Geologiske Undersøgelse, Øster Voldgade 10, DK-1350 København K, Danmark.

This paper results from a preliminary examination of collections of Cambrian fossils obtained during the summer of 1978 in Peary Land, eastern North Greenland (fig. 1), in the first year of a GGU regional geological mapping programme. Most of the collections were made by Peel, but important material collected by R.L. Christie (Geological Survey of Canada), J.R. Ineson (Keele), P.D. Lane (Keele), A.T. Thomas (Aston) and P. Frykman (Copenhagen) was also examined.

Prior to 1978, the best known Cambrian sequence in Peary Land was at Jørgen Brønlund Fjord (locality 7 in fig. 1) where Lower Cambrian sediments are unconformably overlain by dolomites of the Wandel Valley Formation of Late Canadian (late Early Ordovician) to Middle Ordovician age, (Jepsen, 1971; Christie \& Peel, 1977). Reconnaissance work by Dawes (1976 a) suggested the presence of a thicker Cambrian sequence to the west, at Adams Gletscher (localities 2 and 3, fig. 1), and this was confirmed by the 1978 field work.

Peel (1979) has briefly described the approximately $1400 \mathrm{~m}$ thick Cambrian section in the Adams Gletscher area noting the presence of Middle and Upper Cambrian in addition to the Lower Cambrian. Two groups of carbonate rocks were recognised above the Lower Cambrian clastics of the Buen Formation and these were divided into eight as yet un-named formations (fig. 2) - an additional formation of the Brønlund Fjord Group is recognised here. Many of these units can be traced eastward from Adams Gletscher toward Jørgen Brønlund Fjord, but the Cambrian sequence is progressively overstepped by the Wandel Valley Formation. In addi- 


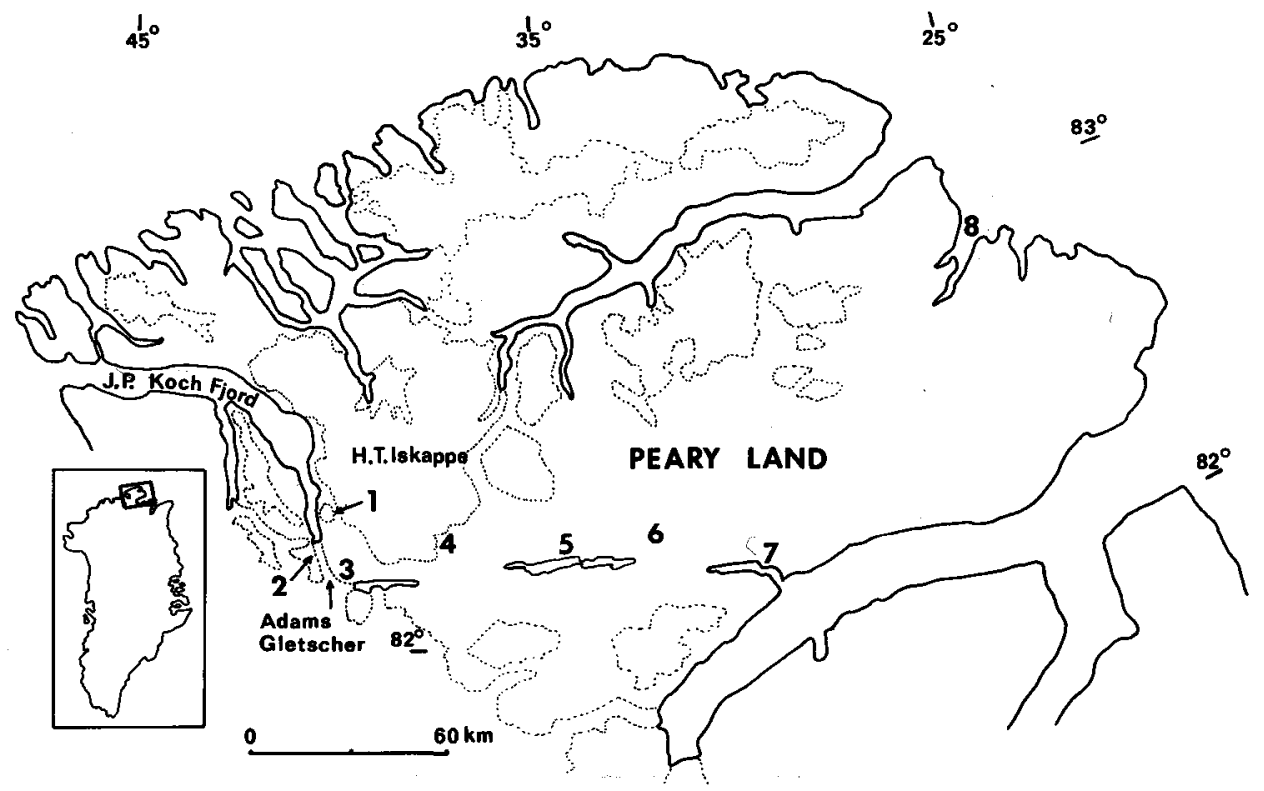

Fig. 1. Cambrian localities in Peary Land. H.T. Iskappe, Hans Tavsens Iskappe. 1, east of J.P. Koch Fjord; 2, west of Adams Gletscher; 3, east of Adams Gletscher; 4, east of Hans Tavsens Iskappe; 5, Midsommersøer; 6, Sæterdal; 7, Jørgen Brønlund Fjord; 8, G.B. Schley Fjord.

tion, most formations exhibit a progressive change in lithofacies from nort-west to south-east, reflecting passage from more offshore to more inshore environments.

Most of the Early Cambrian faunas discussed below indicate the Bonnia-Ollenellus Zone, the uppermost zone of the Early Cambrian. However, olenellids from the Buen Formation include a nevadiid which may suggest a somewhat older age. The early Middle Cambrian is seemingly absent in Peary Land, middle Middle Cambrian strata resting with presumed discontinuity on the Early Cambrian. The Late Cambrian is currently only known from Dresbachian trilobites in formation 2 of the Tavsens Iskappe Group, but most of the overlying unfossiliferous rock units assigned to this group may also be of Late Cambrian age.

\section{Previous reports of Cambrian fossils from Peary Land}

Troelsen (1956) reported a fauna including fragments of olenellids and Salterella from the base of the Brønlund Fjord Group near Midsommersøer (fig. 1, locality 5). This material was briefly noted by Peel, Dawes \& Troelsen (1974) who, in addition, reported hyolithids, Pelagiella, inarticulate brachiopods, Bonnia and other trilobites from Troelsen's collections. Peel \& Christie (1975) and Christie \& Peel (1977) recognised this unit at Jørgen Brønlund Fjord (member A of the Brønlund Fjord Formation, now the basal part of formation 1 of the Brønlund Fjord Group, see fig. 2) and added Calodiscus(?), Chancelloria, Fordilla troyensis, Hyolithellus(?) and Linnarssonia to the faunal list. The unit with its fauna of late Early Cambrian age has now been recognised at several localities as far west as the Adams Gletscher area (Peel, 1979). 


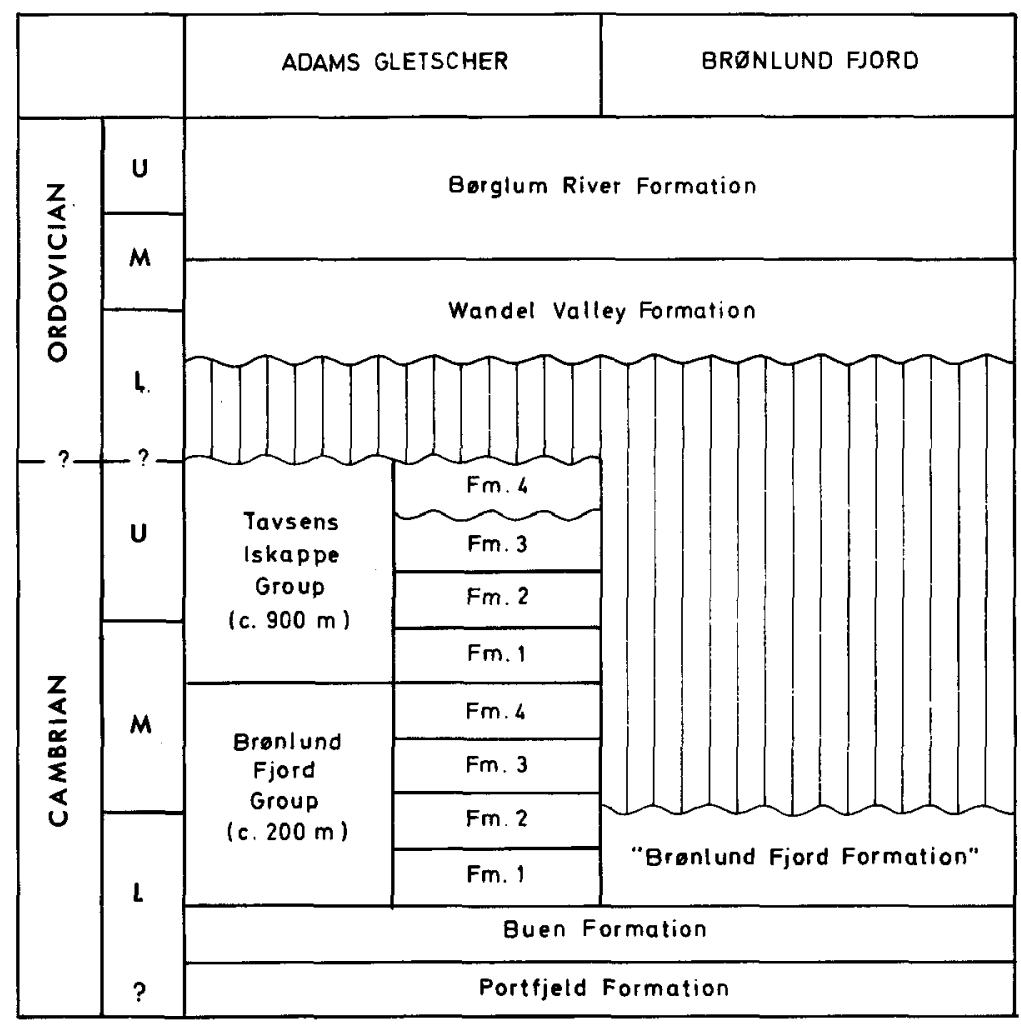

Fig. 2. Cambrian-Ordovician stratigraphy of the Adams Gletscher and Jørgen Brønlund regions of Peary Land (modified from Peel, 1979).

Troelsen (1956) reported olenellids from the G.B. Schley Fjord area of north-eastern Peary Land (fig. 1, locality 8) from a shale unit (Schley Fjord Shale) which seems to be generally equivalent to the Buen Formation of the Jørgen Brønlund Fjord area (Christie \& Ineson, 1979). Poulsen (1974) assigned the olenellids to Olenellus cf. svalbardensis and also described an olenellid, Holmia hyperborea, from shales of the Buen Formation at Jørgen Brønlund Fjord. Additional material from this locality was collected by Christie \& Peel who, in addition to $H$. hyperborea, noted Hyolithus with opercula and helens, Pelagiella, large archaeocopid ostracodes compared with Cambria and an olenellid which was thought to be a Callavia but is now thought to be a nevadiid.

Dawes (1976 a) briefly visited the Adams Gletscher area, recognising some of the rock units subsequently described by Peel (1979). He collected supposed Hyolithellus and Linnarssonia, determined by Peel who suggested a correlation, now known to be incorrect, with the Early Cambrian fauna from the base of the Brønlund Fjord Group. The fossils are from formation 3 of the Brønlund Fjord Group and are of Middle Cambrian age. Peronopsis and Helcionella (Peel in Dawes, 1976a) from higher in the sequence (formation 4 of the Brønlund Fjord Group) were considered to be of Middle Cambrian age and provided the first record of this interval from Peary Land. 
Peel (1979) described the Cambrian sequence at Adams Gletscher, reinterpreting the stratigraphy of Dawes (1976a), and including field identifications of much of the material discussed below.

\section{Portfjeld Formation}

The precise age of the Portfjeld Formation, an approximately $200 \mathrm{~m}$ thick unit of mainly dolomite (Jepsen, 1971), is not known. Its tratigraphic position between the Buen Formation of Early Cambrian age and the Morænesø Formation with tillites correlated with the Varanger sequence in Scandinavia (summary in Dawes, 1976b) indicates a possible late Proterozoic or earliest Cambrian age, but no fossils other than stromatolites and algal(?) threads (Pedersen, 1970) have been recorded.

\section{Buen Formation}

In its type area at Jørgen Brønlund Fjord (fig. 1, locality 7), the Buen Formation (c. $425 \mathrm{~m}$ ) is seemingly composed of two coarsening upwards cycles (Jepsen, 1971). However, to the west, the formation can be loosely divided into a lower unit of thin bedded, bioturbated sandstones and an upper unit of more recessive black shales, siltstones and thin sandstones. Well preserved olenellids from black shales in the upper half of the formation at Jørgen Brønlund Fjord were collected in 1969 by geologists of Greenarctic Consortium and subsequently described by Poulsen (1974).

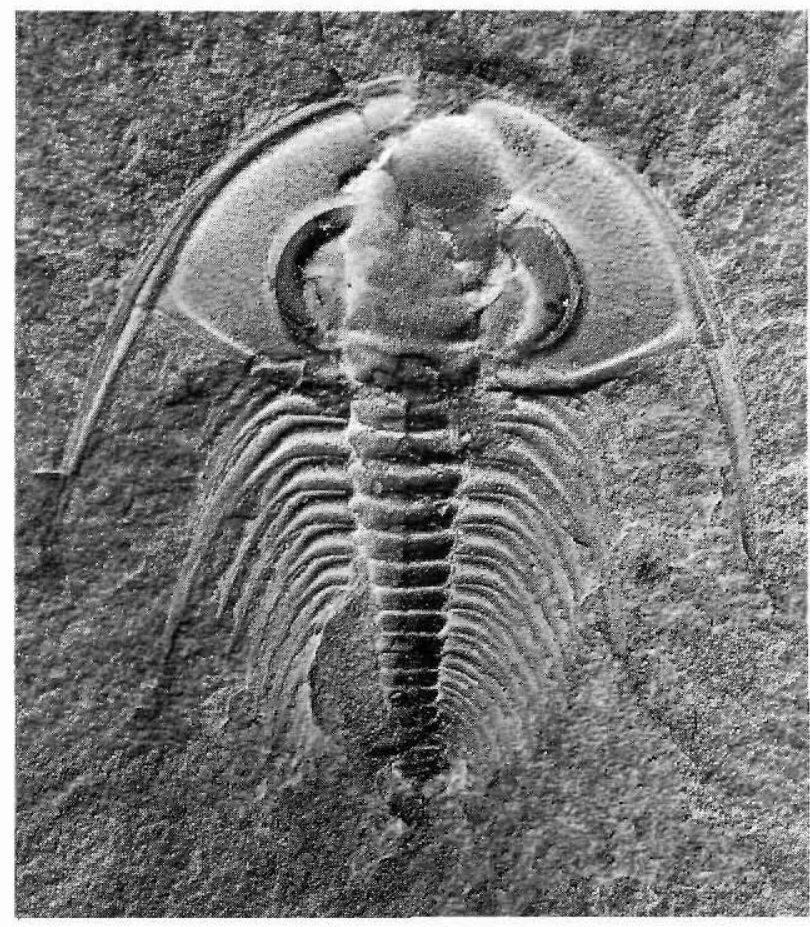

Fig. 3. Holmia hyperborea Poulsen 1974. MGUH 13945 from GGU collection 184219, Buen Formation, locality 7, Peary Land. External mould with light from lower right, $\times 6$. 
Collecting at the type locality and at Sæterdal (fig. 1, locality 6) during 1978 demonstrated two loosely defined olenellid faunas at this level, although the taxa are not mutually exclusive. Lower beds are dominated by a nevadiid with small eyes and an unusual ornamentation of pustules set inside a reticulate pattern (the supposed Callavia of Poulsen, 1974 and Christie \& Peel, 1977). This is associated with Holmia hyperborea Poulsen, 1974 (fig. 3), an archaeocopid ostracode comparable to the Siberian genus Cambria, Serrodiscus and Hyolithellus. The nevadiid becomes rarer upward, such that higher collections are dominated by Holmia hyperborea, commonly associated with abundant hyolithids.

None of the Buen Formation faunas can be unequivocally assigned to the Bonnia-Olenellus Zone of the Early Cambrian, and it is possible that they may represent the medial Early Cambrian Nevadella Zone.

Christie \& Ineson (1979) made large collections of trilobites from the Schley Fjord Shale at several localities in the general area of G.B. Schley Fjord (fig. 1, locality 8) during 1978. Poulsen (1974) has referred specimens from this unit to Olenellus cf. svalbardensis. At least three olenellid taxa are present, associated with Serrodiscus. The material has not been closely studied and its relationship to the Buen Formation faunas is not known.

\section{Brønlund Fjord Group}

Peel (1979) raised the former Brønlund Fjord Formation of Troelsen (1949) and Christie \& Peel (1977) to group status and recognised four constituent formations in the Adams Gletscher region (figs 1,2 ), although these were not formally described. To the east, delimitation of the individual formations is less clear due to changes in lithofacies associated with the general north-west to south-east transition from more basinal to more 'platform' lithologies. Pale, well sorted sandstones with calcareous matrix at Sæterdal (fig. 1, locality 6) can be recognised as a fifth formation, overlying formation 1 . The sandstones grade laterally into the dark shales and dolomites of formation 2 and appear to dominate outcrops to the east of Midsommersøer. Although the sandstones are characteristic, they are generally associated with pale or dark, laminated to thin bedded, dolomites or sandy dolomites. At Jørgen Brønlund Fjord (fig. 1, locality 7), to the south-east of Sæterdal, the sandstones are seemingly entirely replaced by pale, sugary dolomites and dolomite breccias (members $\mathrm{C}$ and $\mathrm{D}$ of the Brønlund Fjord Formation of Christie \& Peel, 1977).

As noted by Peel (1979), the Brønlund Fjord Group is of Early Cambrian to Middle Cambrian age. Faunas have been recovered from all five of the presently recognised constituent formations.

\section{Formation 1 (c. $60 \mathrm{~m})$}

This, the basal formation of the group, overlies the Buen Formation with apparent conformity. Pale weathering, cliff-forming dolomites dominate, but these may be breccia, strongly bioturbated, or a 'heterolithic' complex of wavy laminated pale and dark dolomites. More north-westerly outcrops are generally darker and may be locally cherty, reflecting their more 'basinal' character. 
The formation is probably equivalent to members $\mathrm{A}$ and $\mathrm{B}$ of the former Brønlund Fjord Formation (Christie \& Peel, 1977) at Jørgen Brønlund Fjord and has yielded the 'member A' fauna first located by Troelsen (1956) and noted above. In addition to Bonnia and Calodiscus, these basal beds yield fragments of Wanneria and can be assigned to the Bonnia-Olenellus Zone, the uppermost zone of the Early Cambrian.

\section{Formation 2 (c. $35 \mathrm{~m}-75 \mathrm{~m}$ )}

Dark, recessive, laminated, cherty dolomites, shales, limestones and subsidiary pale sandstones of formation 2 overlie formation 1 at Adams Gletscher and on the eastern side of Hans Tavsens Iskappe (fig. 1, localities 1-4). Peel (1979) located olenellids near the base of the formation in most sections, but found that most of the sequence yielded Middle Cambrian faunas dominated by agnostids.

The distribution of faunas within formation 2 is of particular interest in that the Early Cambrian faunas are apparently followed by middle Middle Cambrian faunas, without representation of the intervening early Middle Cambrian zones. In these relatively 'basinal' sequences the discontinuity can be located to within $3 \mathrm{~m}$ of sequence at locality 4 , but is not generally accompained by pronounced changes in lithology. The discontinuity is widespread in the Appalachian and Arctic regions of North America and is usually represented in more inshore sections by a sandstone unit separating Early and Middle Cambrian faunas. In Peary Land, sandstones of formation 5 of the Brønlund Fjord Group occurring to the south-east of the more basinal formation 2, may in part represent this inshore clastic 'equivalent' of the discontinuity.

Early Cambrian faunas of formation 2 are rich. At locality 1 (fig. 1) olenellids are associated with Fordilla, Hyolithus, Pelagiella and other trilobites. A distinctive species of Kootenia at localities 3 and 4 is associated with Olenellus, Bonnia and Ogygopsis at the latter locality. The faunas are referable to the Bonnia-Olenellus Zone of the late Early Cambrian.

The agnostid dominated Middle Cambrian faunas include species of Ptychagnostus suggestive of the Bathyuriscus-Elrathina Zone and the overlying Bolaspidella Zone, associated with other trilobites, brachiopods, helcionellaceans and Stenothecoides.

\section{Formation 3}

This formation of generally pale weathering, cliff-forming dolomites and dolomite breccias is generally about $40 \mathrm{~m}$ thick, but is reduced to only $8 \mathrm{~m}$ at locality 1 , (fig. 1).

Fossils were only collected at locality 3 and include brachiopods and Hyolithellus. A Middle Cambrian age is evident from its stratigraphic position between formations 2 and 4 .

\section{Formation 4}

This formation attains a thickness of $85 \mathrm{~m}$ at locality 2 , but is reduced to about half this thickness at locality 1 . The typical lithologies at these localities, and locality 4 , are interbedded, recessive, pale grey weathering shales and thin nodular lime mudstones which yield a profusion of well preserved, often complete, trilobites. Species of Elrathina, Ehmania and Peronopsis reminiscent of those described from the Pentagon Shale of Montana by Deiss (1939) are common. The presence of Elrathina is normally considered to be a guide to the BathyuriscusElrathina Zone, but the presence of this fauna obove the Bolaspidella Zone fauna at the top of 
formation 2 highlights some of the problems associated with our current understanding of biofacies (and hence current zonal practice) in these Middle Cambrian inner shelf environments.

At locality 3 nodular limestones at the base of the formation yield an apparent Bolaspidella Zone fauna of Olenoides, Bolaspidella, Elrathina, Bathyuriscus, Ehmania, Alokistocare, Peronopsis, several helcionellaceans and a variety of inarticulate brachiopods.

\section{Formation 5}

At Sæterdal (locality 6 in fig. 1), formation 1 of the Brønlund Fjord Group is overlain by a generally pale weathering unit $(c .100 \mathrm{~m}$ ) dominated by parallel bedded decalcified sandstones with some darker, sandy dolomites. The formation seems to be laterally equivalent to the more 'basinal' formation 2 into which it grades to the west. However, while formation 2 is mainly of Middle Cambrian age, formation 5 has yielded rich Early Cambrian faunas throughout most of its thickness, and no Middle Cambrian.

The fauna is dominated by the same species of Kootenia found in the lower beds of formation 2 at localities 3 and 4 (fig. 1), but also includes Bonnia, Olenellus, several ptychoparoids, Nisusia and a variety of other brachiopods indicate of the Bonnia-Olenellus Zone.

\section{Tavsens Iskappe Group}

The Tavsens Iskappe Group (Peel, 1979) includes about $900 \mathrm{~m}$ of mainly pale weathering, cliff-forming dolomites, with some thin sandstones. The dolomites are of a variety of lithologies, including breccias, oolites and laminated and sugary, recrystallised varieties. Outcrops are mainly concentrated around the southern margin of Hans Tavsens Iskappe and extend as far east as Midsommersøer. The group conformably overlies the Brønlund Fjord Group but is progressively overstepped toward the south-east by the Wandel Valley Formation of late Canadian (late Early Ordovician) to Middle Ordovician age.

The most complete section through the Tavsens Iskappe Group is between J.P. Koch Fjord and the western margin of Hans Tavsens Iskappe (fig. 1, locality 1), where Peel (1979) has tentatively recognised 4 un-named formations.

With the exception of a few inarticulate brachiopods from the basal beds at locality 4 , fossils have only been collected from formation 2 .

\section{Formation 2}

This unit of dark shales and laminated dolomites yielded Hypagnostus from its lowest beds, indicative of a late Middle Cambrian age. Immediately overlying beds contain Kormagnostus and a catillicephalid, confirming a Dresbachian age. Slightly higher collections contain Blountia and Cedaria. Thus, the formation spans the Middle Cambrian - Late Cambrian boundary. Peel (1979) arbitrarily drew this boundary at the base of the Tavsens Iskappe Group. It is here recognised to lie in the lower beds of formation 2 (fig. 2).

The age of the overlying formations 3 and 4 of the Tavsens Iskappe Group is not known. Peel (1979) assumed a general Late Cambrian age, while recognising that the highest beds could be earliest Ordovician. 


\section{References}

Christie, R.L. \& Ineson, J.R. 1979: Precambrian-Silurian geology of the G.B. Schley Fjord region, eastern Peary Land, North Greenland. Rapp. Grønlands geol. Unders. 88, 63-71.

Christie, R.L. \& Peel, J.S. 1977: Cambrian-Silurian stratigraphy of Børglum Elv, Peary Land, eastern North Greenland. Rapp. Grønlands geol. Unders. 82, 48 pp.

Dawes, P.R. 1976a: Reconnaissance of Eocambrian and Lower Palaeozoic strata in south-western Peary Land, North Greenland. Rapp. Grønlands geol. Unders. 80, 9-14.

Dawes, P.R. 1976b: Precambrian to Tertiary of northern Greenland. In Escher, A. \& Watt, W.S. (edit.) Geology of Greenland, 248-303. Copenhagen: Geol. Survey Greenland.

Deiss, C. 1939: Cambrian stratigraphy and trilobites of northwestern Montana. Geol. Soc. Am. Spec. Pap. $18,135 \mathrm{pp}$.

Jepsen, H.F. 1971: The precambrian, Eocambrian and early Palaeozoic stratigraphy of Jørgen Brønlund Fjord area, Peary Land, North Greenland. Bull. Grønlands geol. Unders. 96 (also Meddr. Grønland 192,2) $42 \mathrm{pp}$.

Pedersen, K.R. 1970: Late Precambrian microfossils from Peary Land. Rapp. Grønlands geol. Unders. 28, 16-17.

Peel, J.S. 1979: Cambrian - Middle Ordovician stratigraphy of the Adams Gletscher region, south-west Peary Land, eastern North Greenland. Rapp. Grønlands geol. Unders. 88, 29-39.

Peel, J.S. \& Christie, R.L. 1975: Lower Palaeozoic stratigraphy of southern Peary Land, eastern North Greenland. Rapp. Grønlands geol. Unders. 75, 21-25.

Peel, J.S., Dawes, P.R. \& Troelsen, J.C. 1974: Notes on some Lower Palaeozoic to Tertiary faunas from eastern North Greenland. Rapp. Grønlands geol. Unders. 65, 18-23.

Poulsen, V. 1974: Olenellacean trilobites from eastern North Greenland. Bull. geol. Soc. Denmark 23, 79-101.

Troelsen, J.C. 1949: Contributions to the geology of the area round Jørgen Brønlunds Fjord, Peary Land, North Greenland. Meddr Gronland 149 (2), 29 pp.

Troelsen, J.C. 1956: The Cambrian of Greenland and Ellesmere Island. In El sistema Càmbrico, su paleogeografia y el problema de su base. 20 Congr. geol. int. Mexico. Symp. 3(1), 71-90. 